\title{
MACROECONOMIC FACTORS AND THEIR INFLUENCE ON THE VISEGRAD GROUP EXCHANGE RATES \\ Kitty Klacsánová ${ }^{1}$, Mária Bohdalová ${ }^{2}$
}

\begin{abstract}
The paper analyzes the effects of macroeconomic development on exchange rates and aims to point out indicators with a significant impact on the Visegrad Group's domestic currencies. Steep changes causing the Visegrad Group's currencies to either appreciate or depreciate against the US dollar may result in higher risks for investors and even deteriorate the competitiveness of the particular country. The paper presents several macroeconomic indicators and their influence on four currencies, namely the Czech crown, Hungarian forint, Polish zloty and the Euro. As the Slovak Republic introduced the Euro as its official currency, the paper also analyzes it's impact on the common currency of the Eurozone. To emphasize international competitiveness, the research apart from traditional economic indicators, serving as a focal point in theories for exchange rate determination, incorporated economic complexity and corruption score as well. The findings indicate that during the period between 2000 to 2017, the two common indicators i.e. total reserves and corruption played the key role in determining the yearend spot exchange rates of the Czech crown, Hungarian forint and the Polish zloty. Besides corruption score, economic complexity serves as another significant indicator merely influencing the direction of the Euro's and the Zloty's Dollar exchange rate movement. The last section compares the results of the OLS analyses for each country and verifies their accuracy through robust regressions. Overall, the model for the Czech crown represents the highest accuracy, regarding its predictive ability.
\end{abstract}

JEL Classification Numbers: F31, F41, E40, DOI: https://doi.org/10.12955/peb.v1.26

Keywords: Exchange rate, Macroeconomic factors, Corruption score, Visegrad group countries.

\section{Introduction}

The countries of the Visegrad Group, a regional group of EU member states, have a common history and culture. The Visegrad Group consist of countries with similar economies and yet different domestic currencies, except Slovakia, which has adopted the euro. This regional grouping creates space to find common macroeconomic indicators that can affect their currencies.

This paper aims to develop representative models for the end-year spot exchange rates of the Visegrad Group's currencies as well as to identify significant influencing factors. Finally, concerning the future development of the selected exchange rates, the present study compares the findings to identify indicators with similar or different effects on the dollar exchange rates in terms of intensity and direction of their changes.

The purpose of this paper is therefore to examine each in US dollar - denominated Visegrad Group exchange rate through changes in selected indicators. A wide range of macroeconomic indicators has been taken into account as potential determinants to explain these exchange rates. The present study will provide suggestions to various entities in the economy which are interested in international trade, investment or other forms of currency conversion. Shifts in the values of macroeconomic indicators influencing the exchange rates of a particular currency may urge new policy decisions affecting the large scope of fields that economic players encounter in their activities.

To achieve the objectives, the article proceeds as follows. First, literature review discusses the relevant articles on exchange rates. Then, the article details the methodology and data used for the study. Next, the results are presented and finally, the article concludes by discussing research and its practical implications and suggesting avenues for future research.

\section{Literature review}

Different approaches can be used to explain the exchange rates movement. While some researchers like Civcir (2003) and Meese \& Rogoff (1983) base their analysis on theoretical models, including only monetary variables to create a monetary model, others as Ramasamy \& Abar (2015) consider a wide range of indicators. Mpofu (2016) assumed that factors such as commodity prices, output volatility and trade openness represent indicators with higher influence than monetary factors. Mano et al. (2019) in the IMF's research categorized several economic indicators into macroeconomic, cyclical, financial, structural and policy groups.

Chen \& Rogoff (2003) by studying an in-sample fit, proved that the influence between commodity prices is considerable. Ferraro et al. (2015) incorporated oil prices into their exchange rate model and pointed

\footnotetext{
${ }^{1}$ Comenius University in Bratislava, Faculty of Management, Department of Quantitative Methods, Kitty.klacsanova@fm.uniba.sk

${ }^{2}$ Comenius University in Bratislava, Faculty of Management, Department of Quantitative Methods, maria.bohdalova@fm.uniba.sk
} 
out its increased predictive ability. According to their results, there exists a significant relationship between the oil price developments and exchange rates movements. Khin et al. (2017) provided evidence on the significant influence of the CPI and money supply on exchange rates. While the former is positively related to their analyzed currency, the latter causes an opposite effect. Furthermore, the authors reported a negative relationship between interest rates and exchange rates. Declining domestic interest rates not only reduce foreign direct investments but also cause a lack of motivation to hold savings in the domestic currency. This results in the rising inflation and reduced consumer spending in the domestic economy. Hsing (2016) through demand and supply, examined the determinants of the Hungarian forint's dollar exchange rate employing the EGARCH method. The indicators appreciating the forint are found to be rising domestic interest rates, real GDP, stock market index and declining inflation rates.

Anzuini et al. (2016) analyzed the period of the sovereign debt crisis and established a high-frequency and lower-frequency model for the dollar exchange rate of the euro, including interest rate differentials in different time horizons and sovereign spreads. Their analysis showed the decrease in the sovereign spreads appreciated the euro after year 2012. Furthermore, they pointed out the relative contributions of selected indicators to the development of the USD exchange rate of the euro. The model tested additional variables, namely GDP growth differentials between the euro area and the United States, 3-month nominal interest rate and annual inflation rate differentials, sovereign spreads and bilateral trade balances. According to their variance decompositions, the short-term exchange rate variances are solely explained by their past values. On the other hand, in the long-term, the GDP growth and the inflation represent $20 \%$ of the analyzed exchange rate's variability, while the short-term nominal interest rates account for $7 \%$ of the variability. Increasing short term interest rate differentials appreciate the exchange rate and the euro area inflation depreciates the euro against the US dollar.

In the next section, we propose our own model that analyzes the impact of the selected macroeconomic variables on Visegrad group countries exchange rates using classical and robust approach.

\section{Data and Methodology}

For analysis, data series were collected from the online databases of the Bank of International Settlements, Bank of England, National Bank of Slovakia, World Bank and The Observatory of Economic Complexity. The base year for the indexes was 2015. The data with yearly frequency of the selected economic indicators and end-year exchange rates data has been used. All the Visegrad Group's exchange rates are denominated in USD. All data span from 2000 to 2017.

Commonly used factors to determine exchange rate in literature are the consumer price index (CPI), monetary aggregates, the short-term or long term interest rates, federal funds rate for the United States, industrial production (Meese \& Rogoff, 1983), (Civcir, 2003), (Mano et al., 2019). Moreover Mpofu (2016) have used employment rate, inflation rate, corruption index, gross domestic product, tax rate, borrowing rate and deficit/surplus rate to determine AUD/USD, Euro/USD and AUD/EUR.

The present study analyzes the influence of the following factors on the Visegrad Group's exchange rates:

- The inflation measured by the consumer price index $(C P I)$;

- The government's revenue from income, value-added tax, and other taxes measured as a percentage of GDP (TaxRev);

- The employment rate measured as a percentage in a country $(E M P)$;

- The rent prices measured in an index form $(H C R)$.

- The index of domestic share prices traded internationally as well (ShPrice);

- The long-term interest rate of 10-year government bonds (LTInt);

- The monetary base $M 1$ measured as an index;

- The monetary base $M 3$ measured as an index;

- The logarithms of the total national reserves according to the requirements of the IMF (ln(Reserves));

- The economic complexity of a country $(E C I)$ and

- The corruption score $(C S)$ that represents the countries corrupt practices.

The last two factors considered in the study are not usually used to explain the exchange rates. It is assumed that these factors have the significant impact on exchange rates movements. According to the data from Transparency International (Corruption Perception Index, 2019), The Visegrad Group belongs 
to the countries with comparable corruption score, but still some difference exists. The index of economic complexity $(E C I)$ is an indicator of the level of knowledge in the overall society expressed through its products and services(Mealy et al., 2019).

Data analysis has been done by applying three regression estimates, the multivariate OLS, stepwise and the robust regression. The full and the reduced forms of exchange rate models have been considered in the study. To attain the aims of the research, the following exchange rate model is proposed:

$\Delta F X=\beta 0+\beta_{1} * \Delta C P I+\beta_{2} * \Delta$ TaxRev $+\beta_{3} * \Delta E M P+\beta_{4} * \Delta H C R+\beta_{5} * \Delta$ ShPrice $+\beta_{6} *$ $\Delta L T I n t+\beta_{7} * \Delta M 1+\beta_{8} * \Delta M 3+\beta_{9} * \Delta \ln ($ Reserves $)+\beta_{10} * \Delta E C I+\beta_{11} * \Delta C S+\varepsilon$

where the operator $\Delta$ represents the first differences of the particular economic indicator described above to avoid nonstationary processes.

\section{Results}

This section details the data analyses and its outcomes i.e. to what extent different economic indicators influence the US dollar exchange rate of the Visegrad Group's currencies. The has been tested through regression methods, namely OLS, stepwise and robust regressions were applied on the economic data for the Czech Republic, Hungary, Poland and the Slovak Republic. The results of the OLS regression are presented in Table 1 and Table 4, while the results of the stepwise regression method are presented in Table 2 and Table 5. Finally, Table 3 and Table 6 display the estimates and the summary statistics for the robust regression method.

According to the OLS analysis, the majority of the selected economic indicators do not explain the exchange rate movements in the selected region. Influence of only one variable i.e. the total reserves in the Czech Republic was found to be significant in the studied period. None of the variables influenced the forint and the zloty. In case of the euro, it can be seen that revenues from taxes and economic complexity slightly determine the development of the USD/EUR exchange rate, however, with rather low level of significance. For this reason, significant models were established from only representative variables through the stepwise regression approach with the following results:

Three major macroeconomic indicators have been found to represent the Czech crown's dollar exchange rates:

- Total reserves of the domestic country - In the period of increasing national reserves, the USD/CZK exchange rate tends to decrease, appreciating the domestic currency, the Czech crown.

- Employment rate - Increasing employment resulted in the depreciation of Czech crown.

- It can be expected that higher employment rate would be likewise linked to higher income for domestic subjects, giving them an opportunity for foreign investments and more intensive participation in international tourism. Eventually, this depreciates the particular domestic currency.

- The corruption score - The Czech crown appreciates against the US dollar after eliminating conditions which incite corrupt practices in the Czech Republic.

In case of the model presented in Table 2, only $29.9 \%$ of the variability in exchange rates were kept by incorporating total reserves into the model. Further adding the other variables into the model, explained $69.4 \%$ of the Czech crown's fluctuation (Table 5).

The one-period differences of the rent price index explained $23.4 \%$ of the variability in the Hungarian forint's exchange rate. In case of increasing Hungarian rent prices, domestic currency also appreciated. It means, higher rent prices can lead to increased investments into Hungarian properties from investors holding US dollars. This model is not the most appropriate for the USD/HUF exchange rate modelling due to high values of its residuals' standard deviation.

The stepwise regression model (Table 2) for the polish zloty, including the shares price index, kept $25.5 \%$ variability of the USD/PLN exchange rate (Table 5). Increasing differences in this indicator appreciated the zloty against the US dollar. Better overall performance of investments in the Polish shares created an incentive for investors possessing US dollars to invest them in shares issued in Poland. The dollar exchange rate of the Polish zloty decreased until share prices reached their peak and eventually, they began to fall. 
Considering the Slovak Republic's economic development, a model can be established by employing the stepwise regression method, that consists of two variables. The government's tax revenues and economic complexity explained $43.5 \%$ of the USD/EUR exchange rate's variability.

A one percent increase in the proportion of taxes in the country's GDP meant an average loss of 0.064 on euro investments or for consumers and other subjects holding euros. Further expansion of products by one unit, reflecting extensive know-how of the Slovak Republic, depreciates the euro on an average by 1.414 .

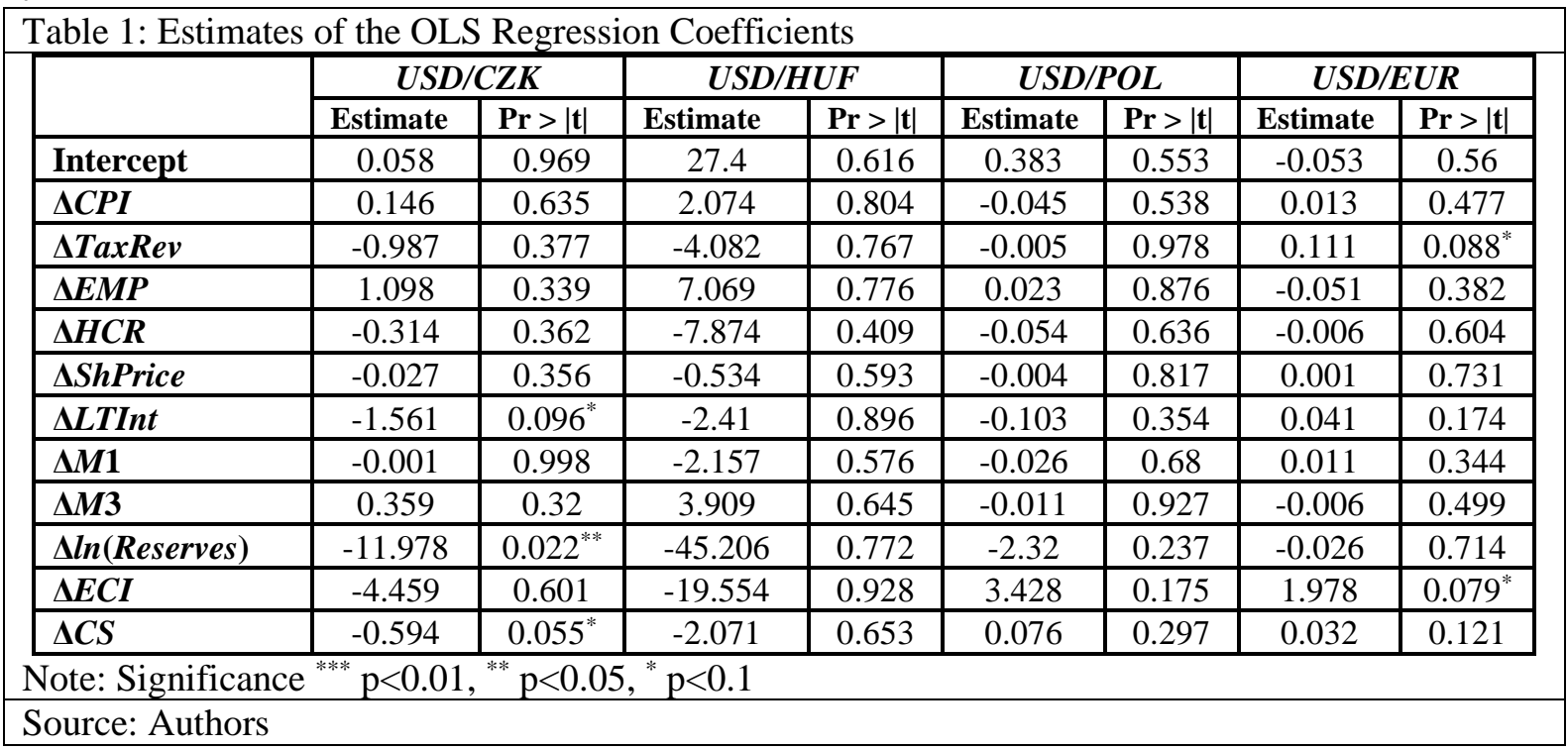

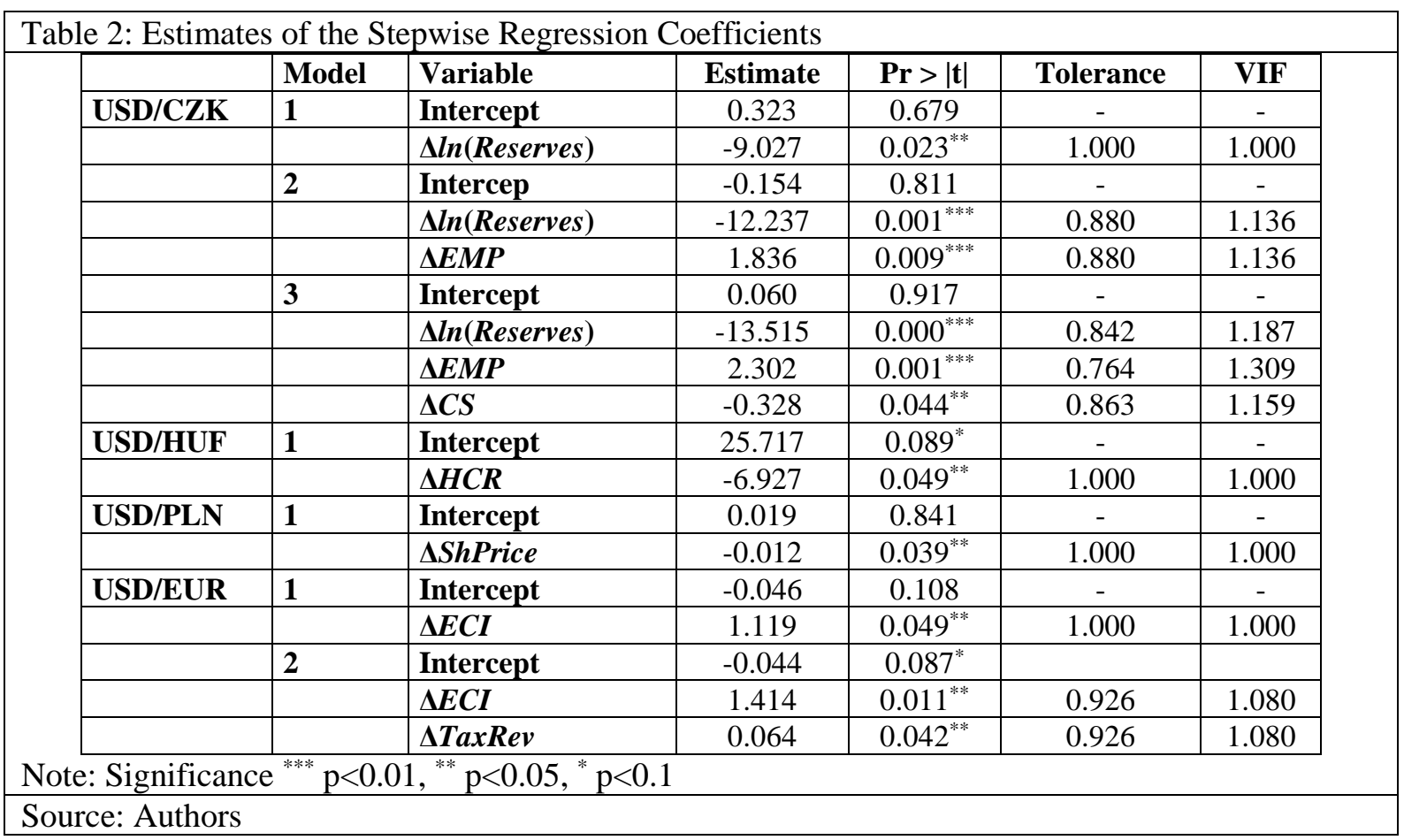

\section{Robust Regression Results}

In this subsection, the results of the OLS and stepwise estimates have been compared with that of the robust regression and the accuracy of the exchange rate model based on differences has been assessed. The research pointed out several other economic indicators that influenced more than one currency of the Visegrad Group.

According to the results, it can be seen that during the period under study each currency was substantially influenced by corrupt practices in the particular country of the region. Regarding the direction of exchange rate movements, the Czech crown and the Hungarian forint are similar in the sense of 
exchange rate appreciation after a favourable corruption assessment in these two countries. On the other hand, during the analyzed period, worsening situation of corruption the zloty and the euro, that worsening situation in terms of corruption appreciated their US dollar exchange rate. Decreasing corruption scores can create a field for a false environment on which investors holding US dollars, Polish zlotys and euros base their trust and preferences. Tightening anti-corruption policies depreciated the zloty and the euro, on an average by 0.114 and 0.026 respectively.

\begin{tabular}{|c|c|c|c|c|c|c|c|c|}
\hline & \multicolumn{2}{|c|}{ USD/CZK } & \multicolumn{2}{|c|}{ USD/HUF } & \multicolumn{2}{|c|}{ USD/POL } & \multicolumn{2}{|c|}{ USD/EUR } \\
\hline & Est. & Prob. & Est. & Pr $>$ Prob. & Est. & Pr > Prob. & Est. & Pr > Prob. \\
\hline Intercept & 0.312 & 0.736 & 46.72 & $0.004^{* * * *}$ & 0.098 & 0.642 & -0.037 & 0.562 \\
\hline$\Delta C P I$ & 0.179 & 0.34 & 9.05 & $0.000^{* * * *}$ & -0.083 & $0.001^{* * * *}$ & 0.012 & 0.359 \\
\hline$\Delta$ TaxRev & -1.264 & $0.056^{*}$ & -7.39 & $0.073^{*}$ & -0.058 & 0.337 & 0.106 & $0.006^{* * *}$ \\
\hline$\Delta E M P$ & 1.113 & $0.099^{*}$ & 6.19 & 0.404 & 0.024 & 0.632 & -0.051 & 0.189 \\
\hline$\Delta H C R$ & -0.31 & 0.127 & -9.30 & $0.001^{* * *}$ & 0.039 & 0.298 & -0.007 & 0.368 \\
\hline$\Delta$ ShPrice & -0.02 & 0.234 & -1.31 & $<.0001^{* * * *}$ & 0.003 & 0.526 & 0.001 & 0.644 \\
\hline$\Delta L T I n t$ & -1.422 & $0.004^{* * * *}$ & 1.59 & 0.774 & -0.209 & $<.0001^{* * * *}$ & 0.043 & $0.025^{* *}$ \\
\hline$\Delta M 1$ & -0.029 & 0.885 & -2.77 & $0.015^{* * *}$ & -0.026 & 0.213 & 0.013 & $0.097^{*}$ \\
\hline$\Delta M 3$ & 0.33 & 0.118 & 3.83 & 0.128 & -0.015 & 0.709 & -0.007 & 0.229 \\
\hline$\Delta \ln ($ Reserves) & -11.47 & $<.0001^{* * * *}$ & -129.88 & $0.005^{* * *}$ & -3.259 & $<.0001^{* * *}$ & 0.013 & 0.788 \\
\hline$\Delta E C I$ & -4.951 & 0.341 & -63.99 & 0.322 & 4.964 & $<.0001^{* * * *}$ & 1.867 & $0.005^{* * * *}$ \\
\hline$\triangle C S$ & -0.595 & $0.000^{* * * *}$ & -6.53 & $<.0001^{* * *}$ & 0.114 & $<000^{* * *}$ & 0.026 & $0.0412^{* *}$ \\
\hline
\end{tabular}

Note: Significance ${ }^{* * * *} \mathrm{p}<0.01,{ }^{* *} \mathrm{p}<0.05,{ }^{*} \mathrm{p}<0.1$

Source: Authors

\begin{tabular}{|l|l|l|l|l|}
\hline \multicolumn{2}{|l|}{ Table 4: Summary of the OLS Regression } & Adj R-Sq & Sig & RMSE \\
\hline & R-Square & 0.658 & $0.076^{*}$ & 1.593 \\
\hline USD/CZK & 0.893 & -0.949 & 0.959 & 39.129 \\
\hline USD/HUF & 0.391 & 0.143 & 0.431 & 0.376 \\
\hline USD/POL & 0.732 & 0.298 & 0.311 & 0.102 \\
\hline USD/EUR & 0.781 & & \\
\hline
\end{tabular}

Note: ${ }^{* * *} p<0.01,{ }^{* *} p<0.05,{ }^{*} p<0.1$

Source: Authors

\begin{tabular}{l}
\hline \multicolumn{1}{|l|}{ Table 5: Summary of the Stepwise Regression } \\
\begin{tabular}{|l|l|c|c|c|c|c|c|}
\hline & Model & $\mathbf{R}$ & $\mathbf{R}^{\mathbf{2}}$ & Adj. R & RMSE & Durbin-Watson & Sig. \\
\hline USD/CZK & 1 & 0.547 & 0.299 & 0.252 & 2.355 & - & $0.023^{* *}$ \\
\hline & 2 & 0.759 & 0.576 & 0.516 & 1.895 & - & $0.002^{* * *}$ \\
\hline & 3 & 0.833 & 0.694 & 0.623 & 1.672 & 1.597 & $0.001^{* * *}$ \\
\hline USD/HUF & 1 & 0.484 & 0.234 & 0.183 & 25.333 & 1.961 & $0.049^{* *}$ \\
\hline USD/PLN & 1 & 0.505 & 0.255 & 0.205 & 0.363 & 2.019 & $0.039^{* *}$ \\
\hline USD/EUR & 1 & 0.483 & 0.233 & 0.182 & 0.110 & - & $0.049^{* *}$ \\
\hline & 2 & 0.660 & 0.435 & 0.355 & 0.098 & 1.864 & $0.018^{* *}$ \\
\hline
\end{tabular}
\end{tabular}

Note: ${ }^{* * *} \mathrm{p}<0.01,{ }^{* *} \mathrm{p}<0.05,{ }^{*} \mathrm{p}<0.1$

Source: Authors

\begin{tabular}{|l|l|l|}
\hline \multicolumn{3}{|l|}{ Table 6: Summary of the Robust Regression } \\
\hline & $\mathbf{R}^{\mathbf{2}}$ & Outlier proportion \\
\hline USD/CZK & 0.830 & 0.118 \\
\hline USD/HUF & 0.475 & 0.177 \\
\hline USD/POL & 0.605 & 0.235 \\
\hline USD/EUR & 0.697 & 0.118 \\
\hline
\end{tabular}

Source: Authors

The total reserves influenced the Czech crown, Hungarian forint and the Polish zloty, whilst long term interest rates in the region were responsible for significant changes in the crown, zloty and the euro. Rising country reserves appreciated the currencies under study on an average from -3.259 to -129.877. Higher returns on government bonds in the Czech Republic, Poland and the Slovak Republic motivated investors holding US dollars to convert their currency into one of these three domestic currencies of the 
Visegrad region. However, the economic condition in Slovak Republic has no sizable impact on the euro.

The differences of the consumer price index are another common indicator for the Hungarian forint and the Polish zloty. With increasing inflation, forint depreciated, and the zloty remained relatively stable. Economic complexity was found to be another significant indicator for the Polish zloty and the euro. Increasing yearly differences in this indicator depreciated the euro and the zloty against the US dollar. One of the many reasons behind this can be the lack of interest among the consumers to purchase goods and services, due to their increased prices, as complex products in terms of knowledge are often more expensive. This decreased the demand for products produced in the Slovak Republic or Poland and consumers along with investors focused their interest on the American market. Eventually, after converting either their savings held in euros or zlotys into dollars, the money supply on the euro's and zloty's side increased.

Apart from the previously described similarities, following additional indicators for the Hungarian forint have been found:

- Rent prices - In case of the robust regression, the effect of rising Hungarian rent prices stayed the same, it appreciated the forint.

- Share prices - The effect of this indicator is linked to an appreciation owing to a favourable outlook on the Hungarian shares market.

- M1- Increasing the Hungarian currency in circulation appreciated its exchange rate against US dollars in the period from 2000 to 2017.

The Slovak Republic's economic indicator that is sole representative for the euro was the tax revenues. As a result of higher income or profits, consumers and firms faced higher tax obligations, therefore, the monetary base in Slovakia increased, resulting in weakening of the euro against US dollars. On the other hand, since this indicator measures tax revenues in percentages of the country's GDP, a constant amount of tax payments in the Slovak republic could depreciate the euro as well, when other components of the GDP decline. To stabilize the USD/EUR exchange rate and to prevent the euro's fluctuation caused by the Slovak Republic's economic development, it may be essential to contemplate a change in the tax rates for different players in the economy.

\section{Conclusion}

This study pointed out the representative macroeconomic indicators in exchange rate determination across the Visegrad Group in the period from 2000 to 2017. A brief overview of several exchange rate models as well as not so common indicators used in exchange rate modelling were discussed. The research assessed the causes of exchange rates oscillations thus assists the decision making in the international trade.

Some of the findings highlighted the significance of the economic indicators discussed in the literature review. Regarding the dynamics of the stock market, the results are in line with the outcomes of Hsing (2016). Favourable conditions in the Hungarian stock market led to appreciation of the forint. Additionally, Hsing (2016) found that rising inflation depreciates the forint, which is also reported by the results in the study.

Interest rates do not extensively represent the Hungarian forint as Hsing (2016) assumed, but instead, they play a relatively more significant role in the development of the Polish currency. The direction of their movements is in line with the results of Anzuini, et al. (2016), however, their research considered short-term interest rates. Khin, et. al. (2017) assumption does not hold true for the Visegrad Group in case of money supply, as this indicator is significant only for the Hungarian forint but with opposite effects as assumed by the authors.

The ordinary least square method under the full model approach yielded different results compared to the stepwise regression. In case of the Czech Republic, there was only one economic variable, total reserves, significantly influencing the end-year exchange rates of the Czech crown. While in the case of the latter regression method, the analysis showed additional significant factors, however with low overall explained variances.

Regarding the results of the robust regression, the least accurate model was established for the Polish zloty and the Hungarian forint as it included the most observations with reduced weights. This approach highlighted the differences between the countries by presenting additional significant indicators not 
considered in the OLS and stepwise regressions. In terms of the explained variability in exchange rate movements, these models are better, especially for the Czech crown (83\%) and the euro (68\%). Each model's residuals fulfilled the basic White noise assumption.

There was one indicator, corruption scores that influenced each currency in the Visegrad Group, however, in most cases it did not cause great changes in the exchange rate of that particular currency.

Considering the extent of influence, the leading indicators with momentous impact on the currencies of the Visegrad Group are discussed further. In case of the Czech crown and Hungarian forint it is found to be country reserves. Increasing country reserves in the Czech Republic and Hungary appreciated the crown by -11.470 and the forint by -129.877 . On the contrary, for the zloty and the euro, economic complexity represents the most significant indicator causing the greatest fluctuation, 4.964 and 1.867.

The findings from this study can serve as a basepoint for assessing investments in the currencies of the Visegrad Group as well as for evaluating opportunities in the international trade. Some steep changes in economic development might signal the need for currency risk hedging or to reconsider international engagement for organizations operating in the countries under study. Regarding the exchange rate regimes in the Visegrad Group, some monetary policy decisions can be expected following steep changes in the economic indicators, especially in the Czech Republic and Hungary, as they did not entirely followed floating exchange rate regimes during the period under study. Therefore, we can expect some interventions from players responsible for the monetary policy in Hungary and the Czech Republic.

For future researches, it is advisable to compare in one model, not only the currencies of the Visegrad Group with a foreign state but also the economic indicators, to receive a different viewpoint. Additionally, analysis on a larger scope of data with higher frequencies and relative values of explanatory variables might yield different results.

\section{Acknowledgment}

This paper was supported by the Comenius University in Bratislava, Grant for Young Researchers No. $384 / 2020$, which the first author gratefully acknowledges.

\section{References}

Anzuini, A., Cecioni, M., \& Neri, S. (2016). Determinants of the Movements in the Euro-Dollar Exchange Rate During the Sovereign Debt Crisis. SSRN Electronic Journal. https://doi.org/10.2139/ssrn.2759823

Chen, Y. C., \& Rogoff, K. (2003). Commodity currencies. Journal of International Economics, 60(1),133-160.

Civcir, I. (2003). The Monetary Model of the Exchange Rate under High Inflation: The Case of the Turkish Lira/US Dollar. Finance a úvěr - Czech Journal of Economics and Finance,53, (3-4). Retrieved from

http://journal.fsv.cuni.cz/storage/927_02_113-129.pdf

Ferraro, D., Rogoff, K., \& Rossi, B. (2015). Can oil prices forecast exchange rates? An empirical analysis of the relationship between commodity prices and exchange rates. Journal of International Money and Finance, 54, 116-141.

Hsing, Y. (2016). Determinants of the Hungarian forint/ US dollar exchange rate. Theoretical and Applied Economics, XXIII (1)(606), Spring, 163-170. Retrieved from http://store.ectap.ro/articole/1168.pdf

Khin, A. A., Yee, C. Y., Seng, L. S., Wan, C. M., \& Xian, G. Q. (2017). Exchange Rate Volatility on Macroeconomic Determinants in Malaysia: Vector Error Correction Method (VECM) Model. Journal of Global Business and Social Entrepreneurship, 3(5), 36-45.

Mano, R. C., Osorio-Buitron, C., Ricci, L.A., \& Vargas, M. (2019). The Level REER model in the External Balance Assessment (EBA) Methodology. International Monetary Fund WP/19/192, 1-40.

Meese, R., \& Rogoff, K. (1983). Empirical Exchange Rate Models of the Seventies: Do They Fit Out of Sample? Journal of International Economics, 14 (1-2), 3-24. Retrieved from https://scholar.harvard.edu/files/rogoff/files/51_jie1983.pdf

Mealy, P., Farmer, J. D. \& Teytelboym, A. (2019). Interpreting Economic Complexity. Science Advances, 5(1), eaau1705. https://doi.org/10.1126/sciadv.aau1705

Mpofu,T. (2016). The Determinants of Exchange Rate Volatility in South Africa. Economic Research Southern Africa working paper [Online], 604, 1-40. Retrieved from

https://www.econrsa.org/system/files/publications/working_papers/working_paper_604.pdf

Ramasamy, R., \& Abar, S. K. (2015). Influence of Macroeconomic Variables on Exchange Rates. Journal of Economics, Business and Management, 3(2), 276-281. https://doi.org/10.7763/joebm.2015.v3.194

Corruption Perception Index (2019): Transparency International is licensed under CC BY 4.0, Retrieved from https://www.transparency.org/en/cpi 